\title{
Lexicography and Linguistic Creativity*
}

\author{
Rosamund Moon, Department of English, University of Birmingham, \\ Birmingham, United Kingdom (r.e.moon.1@bham.ac.uk)
}

\begin{abstract}
Conventionally, dictionaries present information about institutionalized words, phrases, and senses of words; more creative formations and usages are generally ignored. Yet text and corpus data provide ample evidence of creativity in language, showing that it is part of ordinary linguistic behaviour and indeed often systematic.

This article looks at four specific types of lexical creativity in English: figurative meaning, word formation, idioms, and spelling. Focusing on selected examples, it discusses corpus evidence and then treatment in (principally) three recent monolingual dictionaries for learners of English. It argues that, even taking into account the pedagogical function and limited scope of these dictionaries, more could be said about creative aspects of lexis, and the systematicity of creative usage. This would be of benefit and interest to dictionary users, and empower them.
\end{abstract}

Keywords: AFFIXATION, CORPUS, CREATIVITY, DICTIONARY COVERAGE, ENGLISH, FIGURATIVE LANGUAGE, IDIOMS, LEXICOGRAPHY, NEOLOGISM, NORMATIVENESS, SPELLING, WORD FORMATION

Opsomming: Leksikografie en taalkreatiwiteit. Normaalweg verskaf woordeboeke inligting oor geïnstitutionaliseerde woorde, frases en betekenisse van woorde; meer kreatiewe vorminge en gebruike word gewoonlik geïgnoreer. Tog bied teks- en korpusgegewens volop bewyse van kreatiwiteit in taal, wat toon dat dit deel van gewone taalkundige gedrag is en inderdaad dikwels sistematies.

Hierdie artikel beskou vier spesifieke soorte leksikale kreatiwiteit in Engels: figuurlike betekenis, woordvorming, idiome, en spelling. Deur op uitgesoekte voorbeelde te fokus, bespreek dit korpusbewyse en daarna behandeling in (hoofsaaklik) drie resente eentalige woordeboeke vir aanleerders van Engels. Dit voer aan dat, selfs al word die opvoedkundige funksie en beperkte omvang van hierdie woordeboeke in ag geneem, meer gesê sou kon word oor die kreatiewe aspekte van leksis, en die sistematisiteit van kreatiewe gebruik. Dit sal tot voordeel en belang van woordeboekgebruikers wees, en hulle bemagtig.

Sleutelwoorde: AFFIGERING, KORPUS, KREATIWITEIT, WOORDEBOEKDEKKING, ENGELS, FIGUURLIKE TAAL, IDIOME, LEKSIKOGRAFIE, NEOLOGISME, NORMATIWITEIT, SPELLING, WOORDVORMING

* An earlier version of this article was presented as a keynote lecture at the Twelfth International Conference of the African Association for Lexicography, organized by the Tshwane University of Technology in collaboration with the IsiNdebele National Lexicography Unit, at the Soshanguve Campus, Pretoria, Republic of South Africa, 27-29 June 2007.

Lexikos 18 (AFRILEX-reeks/series 18: 2008): 131-153 


\section{Introduction}

It could be argued that lexicography has little business with linguistic creativity. Most dictionaries are essentially normative, and even if they aim at description rather than prescription, their object of description is generally the standard form of a language or dialect. As a result, creative phenomena such as metaphor, neologism, wordplay, and other exploitations are only considered to be part of the lexicon, and therefore worth including in a dictionary, when evidence suggests that a usage recurs and has become institutionalized.

Creative uses of language have, of course, long been discussed within linguistics: for example, in the contexts of humour (Nash 1985, Chiaro 1992), word coinage (Bauer 1983, Katamba 1994), and spoken interaction (Carter 1999, McCarthy 1998). Within Britain, interest was revitalized in 2004 by the publication of Carter's Language and Creativity: The Art of Common Talk, followed by, amongst others, Maybin and Swann's The Art of English: Everyday Creativity in 2006 and Aitchison's The Word Weavers: Newshounds and Wordsmiths, an exploration of journalistic creativity, in 2007. A repeated point is that linguistic creativity is a normal part of language behaviour:

So the main theme of the book is that creativity is an all-pervasive feature of everyday language. And, as I shall say more than once, linguistic creativity is not simply a property of exceptional people, but an exceptional property of all people. (Carter 2004: 13)

In this book, we suggest that the kinds of language creativity and artistry found in art and literature can also be found in the communication practices of everyday life ... We see language creativity as including both textual artistry and also the ways in which people use language creatively to construct identity and manage relationships with others ... (Maybin and Swann 2006: 1)

The kinds of lexical phenomena which they address can be exemplified by the following, taken from Carter (bold font added):

$<$ S01 $>$ : He's at it again but he really wants you know just to sit down.

$<$ S02 $>$ : Like they just talk about how they both feel.

$<$ S01 $>$ : Out of the frying pan into the deep freeze this time.

(2004: 95)

A: He won't forget this time.

B: Brian, can you see those pigs over my left shoulder moving slowly across the sky?

(A and B both burst into laughter)

(2004: 23)

$<$ S01 $>$ : There, that's solid now.

$<$ S02>: I think I've made it unsolid ... sorry ... I've done it the wrong way round, have I?

(2004: 99) 
As Carter discusses, the first involves wordplay, the manipulation of the idiom out of the frying pan into the fire, and metaphorical exploitation of deep freeze; the second alludes to the idiom pigs might fly, indicating disbelief; and the third non-standard affixation. Other kinds of creative usage include:

Rosamund, I'm hotelled out. I looked at c 100 hotels + I've got a short list of 4 . You might like to look at their websites [etc.]. (written personal communication, December 2006)

Overheard also at Hay, aesthete and uber-adapter Andrew Davies wondering whether he really couldn't manage to "find a part in my next screenplay" for one of the nice Royal Ballet dancers performing so pleasingly ... (The Guardian, 1 June 2007)

where be hotelled out and uber-adapter are nonce-formations. Another kind relates to non-standard spellings, such as:

Heston's a renowned chef who specializes in ker-azy scientific cooking. He's best known for serving things like snail porridge and egg-and-bacon ice cream. (The Guardian, 20 October 2007)

Here ker-azy is used to suggest a lengthened and emphatic pronunciation of crazy. Similarly with bares out in the following (though most would consider this an error for bears out):

The [solar-powered] boat registers an electricity gain during a full moon ... It bares out research, that was greeted with scepticism some years ago, that claimed there was a minute, but measurable, increase in temperature during a full moon. (The Guardian, 11 December 2006)

Such cases are not institutionalized as lexical items: consequently, they could be considered outside the English lexicon, and beyond the scope of ordinary dictionaries which set out to describe that lexicon. ${ }^{1}$ Yet they represent recurrent and productive patterns of usage: something that could be described as systematic creativity, and something that is very much part of the lexicon. By 'systematic creativity' I mean cases where individual words, phrases, and affixes are regularly used in creative ways to produce variations of meaning, including connotation and pragmatic effect. It is systematic in the same way that polysemy can be systematic (Apresjan 1974, Ostler and Atkins 1991, Nunberg and Zaenen 1992). ${ }^{2}$ There is copious evidence for systematic creativity in everyday discourse, as Carter and others point out; there is also copious evidence in corpora, although corpora are generally used in lexicography to ascertain how language is 'centrally and typically' used (Hanks 1987: 124-5 and elsewhere) rather than eccentricities and exploitations, which are usually ignored. ${ }^{3}$

Thus systematic lexical creativity in English forms the topic of the present article. It looks in turn at four types of creativity: word meaning, affixation, idiom form, and respelling. For each type, it discusses corpus evidence, drawing on data from the 450-million word Bank of English $(\mathrm{BoE}){ }^{4}$ it then discusses 
their treatment in dictionaries, specifically three recent British monolingual EFL/ESL dictionaries (see section 2.4.1). While the selection of examples to explore will necessarily be limited, I hope to demonstrate something of the extent of the phenomenon of systematic creativity, and the implications for lexicography, including the challenge to the normative function of dictionaries.

\section{Words}

\subsection{Figurative uses}

One obvious way in which words are exploited creatively is through figurative extension. Lexicographical choices are relatively straightforward: if the usage recurs sufficiently, it needs to be recorded, and the more established the usage, the more likely it is to be treated as an independent sense or subsense. For example,

It is a perspective which preserves a sense of the limitations of dependency theory and avoids the simplistic reductionism so common among the present-day butterfly collectors who abound in the social sciences and who stroll through history classifying types of dependency, modes of production, and laws of development, with the blissful illusion that their findings can remove from history all its ambiguities, conjectures and surprises ... (BoE: nonfiction)

Perspective 'viewpoint, stance' is historically a metaphor, but few dictionaries would label it as such, and many would prioritize this sense, the dominant usage, over any optical or architectural ones. In contrast, the metaphor butterfly collectors (not altogether transparent) is infrequent: though there is evidence in BoE of butterfly collector/collecting/collection being used by different writers to suggest an artificially abstract and somewhat opportunistic approach, the usage is not sufficiently institutionalized to be recorded as a sense, even in the unabridged Oxford English Dictionary.

The metaphorical use of stroll is transparent, and demonstrates a regular use of verbs/nouns relating to movement to describe intellectual and verbal behaviour (cf. the systematic conceptual metaphors described by Lakoff and Johnson 1980):

When you hear Balmain boy Alex Lloyd's debut album, Black The Sun, you take a stroll through rock music's past, present and future.

Burke invites you on an odyssey that begins in the present day and travels through history to bring to life the remarkable nature of inter-connected events and discoveries.

I was rather surprised by how little encouragement the students were given to wander off down the byways of the subject.

Yet BoE contains only isolated instances of noun/verb stroll with such a meaning, and so this too is probably one to be considered as an ad hoc usage, 
and ignored - the only really recurrent metaphorical uses of stroll in BoE relate to easy victories:

And - four days after the UEFA Cup win in Germany - they strolled to victory over Airdrie to book a place in the League Cup final.

Dealing with cases like these (or the metaphorical use of deep freeze in the very first example in Section 1) is part of normal lexicographical practice with respect to the analysis and representation of polysemous words. Figurativeness is part of systematic creativity, but it is not really this kind of creativity which concerns me here.

\subsection{The construction of figurativeness}

A more intriguing case, though, is that of words which seem to create figurativeness in their co-texts. For example, a minor subclass of English adjectives comprises items such as archetypal, proverbial, quintessential, ubiquitous, veritable, and so on: they are mainly formal and/or Latinate, and interesting because of their functions in discourse, rather than their literal meanings. Only rarely does proverbial mean 'relating to proverbs'; far more often it is used to mark the use of a particular linguistic item - occasionally a proverb, more often an idiom or part idiom, metaphor or connotative item, and sometimes substituting for a word euphemistically. It is a preemptive device, distancing writers/speakers from their choice of lexis. The following BoE examples are typical:

\footnotetext{
to squeeze through the eye of the proverbial needle). <p $>$ But, alas, it's not fine and that Tailhook is just the proverbial few bad apples, or that there-me election, we Tories were given the proverbial boot, and the more soberly dresse scarcely large enough to swing the proverbial cat. Instead, builders are creati that's for sure. Poor as the proverbial church mice, we are now. In fact has now taken to showing like the proverbial duck to water." $<p>$ Roy Creber's will not sell. What will sell like proverbial hot cakes is his story about Ferg had not ruled her family with the proverbial rod of iron, but with an influec omparison had been financed on the proverbial shoe-string." P. G. WODEHOUSE aut but eventually caught on like the proverbial wildfire; Bagatelle acquired a lo turing qualities. Here was the proverbial able woman behind a gifted man. things and study things. It's the proverbial aim, aim, aim, aim. And never pul can feel uncomfortably like the proverbial bacillus invading a weakened have any content). It's geeky (the proverbial boys in their bedrooms). Digital is a hit. Our visit was on the proverbial dark and stormy night. To get to ental and spiritual satiety on the proverbial desert island. $<p>$ Not content wi she said. Doran looked like the proverbial old friend who arrives at the repeated as drearily as the proverbial old broken gramophone record. She had a constitution like the proverbial ostrich. She never knew what it us. We didn't shout or throw the proverbial plates at each other. Why should sustained from falling down the proverbial slippery staircase. One common $y$ that was made in private, in the proverbial smoke-filled rooms, and sealed by ket. It has continued to climb the proverbial wall of worry after the briefest scratches as it advances up the proverbial ladder of success. At long last spoiled rotten as a child - the proverbial 'unsatisfactory eldest son" -

joy - or they can be a pain in the proverbial. The same can be said of partners and remain mad about the son-of-a-proverbial. They say that they know they sho
} 
It is the second grouping which represents systematic creativity, where proverbial signals something which is meant to be interpreted in a figurative or symbolic way.

Similarly, ubiquitous could be glossed as 'occurring everywhere', but BoE evidence suggests that it is normally hyperbolic. In particular, the ubiquitous seems to indicate that the reference of the following noun group is symbolic, connotative, and something of a cliché (the ubiquitous club sandwich, grey suit, droopy rucksack, sneakers):

owed a great deal to Macintyre's "ubiquitous and enthusiastic support". He was

to come in on the act. Clays are ubiquitous at the Earth's surface. Under the of a superior arbiter, such as ubiquitous British ministers, local

hardening delights rather than the ubiquitous club sandwich. Appetisers include

girl, one shoulder bearing the ubiquitous droopy rucksack and the other a

a million square metres of the ubiquitous floor covering) was still selling $<p>A$ host of tiny villages, ubiquitous flower pots, whitewash and grey

get a degree in law, acquire the ubiquitous grey suit (only $12 \%$ of chief

and retro clothes in contrast to ubiquitous hippie gear, quickly became the

is in many fats and protein is ubiquitous in food (meat, fish, eggs,

nuoc mam, the fermented fish sauce ubiquitous in Vietnamese cuisine, wafted up

ever popular Border Collie and the ubiquitous Jack Russell Terrier. <p> Dogs and pork), shin of beef, the ubiquitous poulet Brittany produces a third

hospital or clinic. Not even the ubiquitous radiation hazard signs or the

DAMN QUEER $</ h><p>$ Venue: The ubiquitous "Secret London Location". Makes a

is the one thing, along with the ubiquitous sneakers, that even the most cash

or less. And then this: rot and ubiquitous tropic heat and atmospheric

a world different from our own ubiquitous tropics. But no more! And

subtle alternatives to the once-ubiquitous vindaloo and Madras. 'We've come our distribution networks are ubiquitous worldwide. We have the leading

Veritable has no real denotative meaning at all, but functions as an emphasizer: ${ }^{5}$

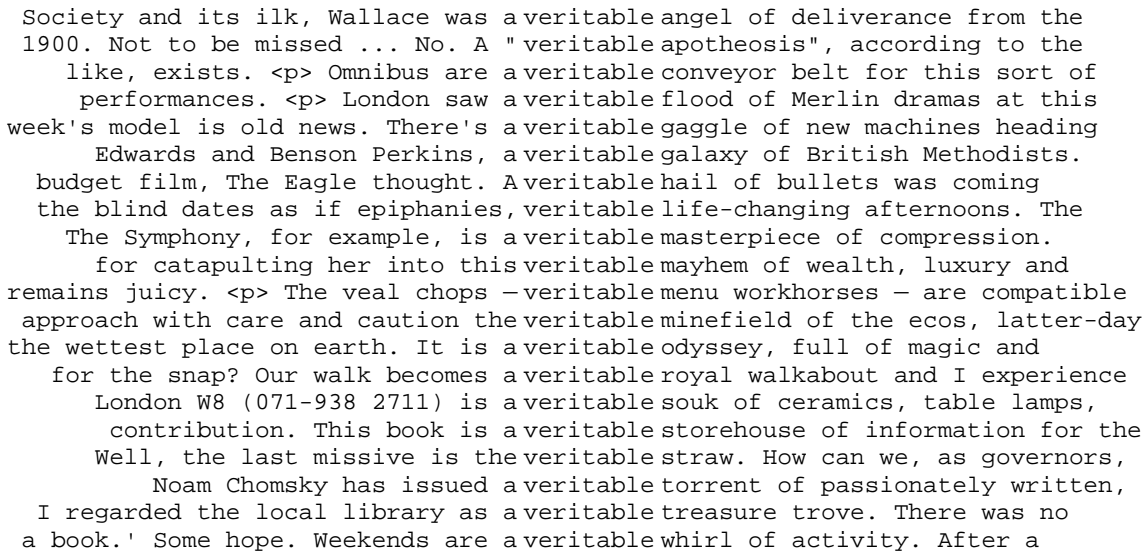

The typical metaphorical status of the following noun is further demonstrated by a list of the most significant items found in BoE after veritable: in descending order, using mutual information statistics, these are cornucopia, smorgasbord, potpourri, fount, menagerie, Aladdin's cave, hotbed, goldmine, feast, minefield, encyclopedia, inferno, banquet, blizzard, torrent, plethora, treasure (trove), avalanche. 
Many of these collocates - and others - refer to complex or multi-faceted entities.

These words are not intrinsically creative, but they all signal some kind of exploitation of the co-text: in particular that the following item is not to be taken literally, but understood in terms of its connotations and implications. This in itself is a creative use of referential meaning.

\section{3 'I'm hotelled out'}

While English phrasal verbs are often regarded as idiomatic and idiosyncratic combinations, there are consistent patterns of usage, with consistent meanings of particles. Out, for example, occurs in combinations relating to eradication and disappearance (airbrush out, die out, phase out, weed out, wipe out); depletion and exhaustion (run out, sell out, tire out); completeness (carry out, flesh out, sort out, spread out); and allocation (mete out, parcel out, share out). Such meanings may be explained in dictionary entries for particles, and their systematic metaphoricity is discussed by, among others, Kövecses and Szabó (1996) and Lindstromberg (1997). Be hotelled out fits best with combinations referring to exhaustion (be burned/played/tired/worn out), and closely corresponds to informal be partied/shopped out, which recur in BoE, and other such combinations which do not.

If you are still all partied out after the New Year, pick up a pick-me-up.

... the Priory group of hospitals - famous for treating the addictions of partiedout celebrities.

Some feel shopped out after a grand fling with consumerism during the mid 80s.

We decided we were all business-conferenced out and we wanted to help young entrepreneurs find balance in their lives.

All Buena Vista'd out? Cachaito Lopez will get you back into the swing, says Nigel Williamson.

This suggests a specific creative phrasal verb frame, be VERBed out, where VERB is supplied by a word that is predominantly used as a noun, with the whole referring to a state of having had too much of the thing denoted by the noun.

\subsection{Dictionary treatment}

\subsubsection{The dictionaries}

To explore how current dictionaries deal with such phenomena, discussion here focuses on treatment in three British monolingual dictionaries for advanced learners of English as a foreign or second language: the Longman Dic- 
tionary of Contemporary English (4th edition, 2003, henceforth LDOCE4), the Oxford Advanced Learner's Dictionary of Current English (7th edition, 2005, henceforth OALD7), and the Macmillan English Dictionary for Advanced Learners (2nd edition, 2007, henceforth MED2). All three dictionaries aim primarily to cover mainstream vocabulary, concentrating on central usage, and their pedagogical function means that they have to be normative: to expect them to deal with creative usage might therefore seem unreasonable. Yet these dictionaries, perhaps more than larger dictionaries for first-language speakers, are very responsive to language change and they have developed a variety of flexible techniques for describing different linguistic phenomena. The three selected dictionaries, the three market leaders, have undergone major revisions in recent years, taking corpus evidence into account: MED was written from the outset with corpus data. Moreover, all need to keep their target users (students in their late teens or early twenties) clearly in mind, along with the kinds of English lexis and globalized discourse to which those users are exposed, including electronic media where creative phenomena abound. In many respects, therefore, they represent a cutting edge of lexicography, driven on by a changing market and the need to show clearly how lexis actually works in current English around the world.

\subsubsection{Some entries}

To begin with proverbial, all three dictionaries treat it in terms of its usage in collocation with fixed expressions:

LDOCE4: the proverbial sth used when you describe something using part of a well-known expression: The store had everything including the proverbial kitchen sink.

OALD7: used to show that you are referring to a particular proverb or wellknown phrase: Let's not count our proverbial chickens.

MED2: used when you are describing something with an expression from a proverb: He turned up just like the proverbial bad penny.

However, these explanations do not account for collocations with other figurative items, nor the way in which proverbial signals that the following noun is to be interpreted metaphorically or in terms of connotations.

Ubiquitous and veritable receive contrasting treatments. The first is labelled 'formal', and given definitions which cover its literal meaning; its weakened sense is conveyed through seeming and humorous(ly) in LDOCE4 and OALD7, and in all three through the implied hyperbole of examples (where the choices of noun collocate to mention may not be as meaningful to dictionary users as to lexicographers).

LDOCE4: formal seeming to be everywhere - sometimes used humorously: Coffee shops are ubiquitous these days. | a French film, starring the ubiquitous Gérard Depardieu. 
OALD7: (formal or humorous) seeming to be everywhere or in several places at the same time; very common: the ubiquitous bicycles of university towns $\diamond$ the ubiquitous movie star, Tom Hanks.

MED2: formal present everywhere: Their HQ comprises miles of corridors with their ubiquitous coffee machines.

The pragmatics of veritable, however, are shown explicitly in definitions, with MED2 also offering a partial paraphrase real; LDOCE4 gives real as a 'synonym', OALD7 gives positive. All label veritable as formal, with OALD7 adding 'or humorous'.

LDOCE4: formal a word used to emphasize a description of something: = real The area is a veritable paradise for those who love walking and swimming.

OALD7: (formal or humorous) a word used to emphasize that sb/sth can be compared to sb/sth else that is more exciting, more impressive, etc. SYN POSITIVE: The meal that followed was a veritable banquet.

MED2: formal real: used for emphasizing what you are saying: a veritable feast $\bullet$ veritable army of helpers

In each case, examples show metaphorical and hyperbolic noun collocates for veritable, but nothing more is said or shown about the typicality of this kind of collocation. (In contrast, the New Oxford Dictionary of English (1998), a large monolingual dictionary for native speakers, says of veritable 'used as an intensifier, often to qualify a metaphor: the early 1970 s witnessed a veritable price explosion'. However, it does not treat the other items and usages examined here in any more depth.)

The dictionaries could not be expected to cover be hotelled out, or really the relevant use of out - though MED2's study page feature on word formation comments on phrasal verb particles having recurrent meanings. Particle meanings are discussed more fully in some EFL/ESL dictionaries of phrasal verbs. For example, the Collins Cobuild Dictionary of Phrasal Verbs (1989) had a separate appendix on particles, and be hotelled out seems to fit with a category 'ending of activities', where the discursive explanation includes

... Some combinations indicate that an activity cannot continue any longer, because all the things or people involved have been used up or destroyed ... These combinations are often passive. For example, if you are played out, you are exhausted and feel unable to do anything.

Macmillan Phrasal Verbs Plus (2005) has a series of sophisticated entries for particles in the main alphabetical sequence of the dictionary: here graphics are used extensively to show relatedness of meanings. The closest senses to that in be hotelled out are those represented under out in relation to 'removing':

have nothing left, be finished (run out, sell out)

stop existing, end, disappear (burn out, fade out, go out) 
But far more significant is the dictionary's special feature 'New' Phrasal Verbs in its pedagogical mid-matter. It explicitly discusses creativity and this specific use of out:

In 2003, the celebrity cook Delia Smith was quoted as saying that she was 'all reciped out' when she announced her intention to retire from TV cookery programmes ...

... writers and speakers often use words in creative ways, but dictionaries do not generally describe these individual creative acts. Nevertheless, we understand what Delia means, because the expression she has created follows a pattern that we are already familiar with ...

A later part of this feature talks about combinations such as be partied out. This feature provides one of the strongest acknowledgements of creativity in current learners' dictionaries, both general and specialized; but it is not part of the main alphabetical text, and the entry for out itself does not cross-refer to the discussion.

To summarize this section, it could be said that the dictionary entries discussed in this section are reasonable attempts to cover usage; the issue is that more could be said, and the extra might help explain a systematicity which underlies these kinds of usage.

\section{Word formation}

\subsection{Affixation}

In an example given in Section 1, the designation uber-adapter was applied to the British screenwriter Andrew Davies, who is noted for his imaginative and elegant adaptations for television of literary novels, including classics such as Pride and Prejudice and Bleak House. Uber- is an odd prefix in English. German in origin, it echoes Übermensch, which is now considered unacceptable because of its eugenecist and racist historical associations, yet these associations do not cross over into English, where it occupies something of the semantic space of super-, mega-, hyper-, as a slightly ironic, currently fashionable, indicator of notoriety, superiority, or domination. In terms of morphology, uber- scarcely occurs at all in institutionalized words - other, perhaps, than uber-babe or ubercool - but is mainly found in a considerable number of ad hoc formations. Those attested in BoE fall into sets: relating to young people (uber-babe, uberbrat, uber-geek, uber-nerd, uber-teens); the entertainment industries (uber-director, uber-entertainer, uber-guitarist, uber-rockster, uber-star); other careers or origins (uber-capitalists, uber-careerist, uber-chef, uber-lawyer, uber-Dubliner); and, in adjectives, to fashionable status (uber-chic, uber-cool, uber-glam, uber-groovy, uber-hip). Thus it is used creatively, to label and emphasize, and also to mock, partly by distancing the writer/speaker from both label and labelled.

The suffix -esque has a much longer history in English, occurring after nouns or names in well-established adjectives such as picturesque and also 
statuesque, rubenesque, junoesque, referring to (mainly female) body types. It is used productively after the names of writers, artists, entertainers, politicans and so on, to form adjectives which indicate or allude to qualities typical of the person mentioned. Better-attested formations, sometimes hyphenated, in BoE include Kafkaesque, Clintonesque, Disneyesque, Beatlesque, Dylanesque, Reaganesque, Abbaesque, Kiplingesque, Chandleresque, Daliesque, Pinteresque, Stalinesque, Capraesque, Chaplinesque, Garboesque, but the creative potential is perhaps best demonstrated in context, in this case with a sample of hyphenated forms where names begin with $W$ :

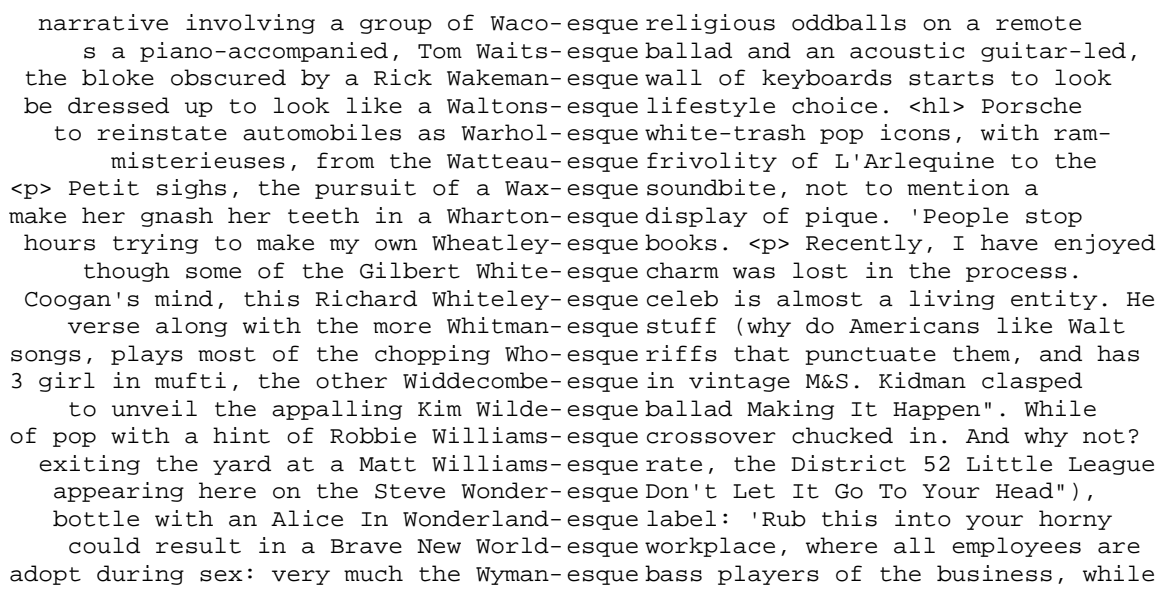

These mainly occur in journalistic components of BoE, and include references to places (Waco), books (Alice in Wonderland, Brave New World), and entertainers, TV personalities, and celebrities: all symbolic of current culture, though references and relatedness are essentially vague. Very few of these ad hoc or creative formations evaluate positively; most are negative, and imply 'less good than' or 'imitative'.6 This contrasts with the better-attested formations, which mainly have more specific meanings and often neutral or positive evaluations.

\subsection{Analogy and blending}

Other new words are formed through analogy or blending, by being modelled on an existing word rather than by combination of established morphemic elements. One such case involves literati, a 17th-century borrowing into English from Latin, and used to refer to highly-educated and cultured people, sometimes with an implication of elitism:

of 'fashion and the longings of literati", and there is no need to say with a large number of vieux Soholiterati, the ones that go in for very long face and announced to the assembled literati that it was good to meet a real 83 ) and the available Concordliterati and transcendentalists; more often Net Book Agreement; unlike other literati, the average Irish writer tends to 
This has generated a blend glitterati, referring to celebrities in the entertainment and other industries:

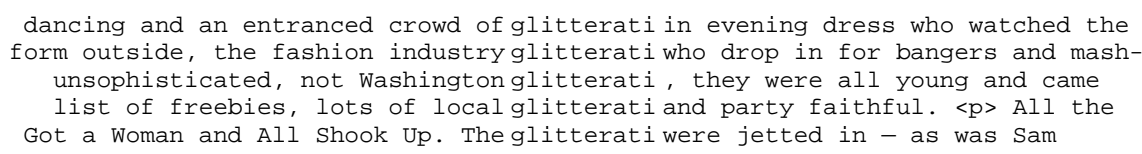

dancing and an entranced crowd of glitterati in evening dress who watched the form outside, the fashion industry glitterati who drop in for bangers and mashunsophisticated, not Washingtonglitterati, they were all young and came list of freebies, lots of local glitterati and party faithful. $<p>$ All the Got a Woman and All Shook Up. The glitterati were jetted in - as was Sam

BoE has 185 tokens of literati, 196 of glitterati. It also provides evidence of many further formations with an ending -erati and indicating cliques of people who are characterized by a particular lifestyle, interest, or trait. There are 8 tokens for chatterati (people who regularly appear as pundits on television and in the media generally, sometimes referred to as 'the chattering classes'): for example,

the anti-science views of the chatterati. Science actually works. And it in the right place. To the mediachatterati, to be 'vulgar" or Northern has And I think there's a high-level chatterati perception, which is, I guess,

Of other formations in BoE, rockerati occurs 3 times, the rest just once or twice: ${ }^{7}$

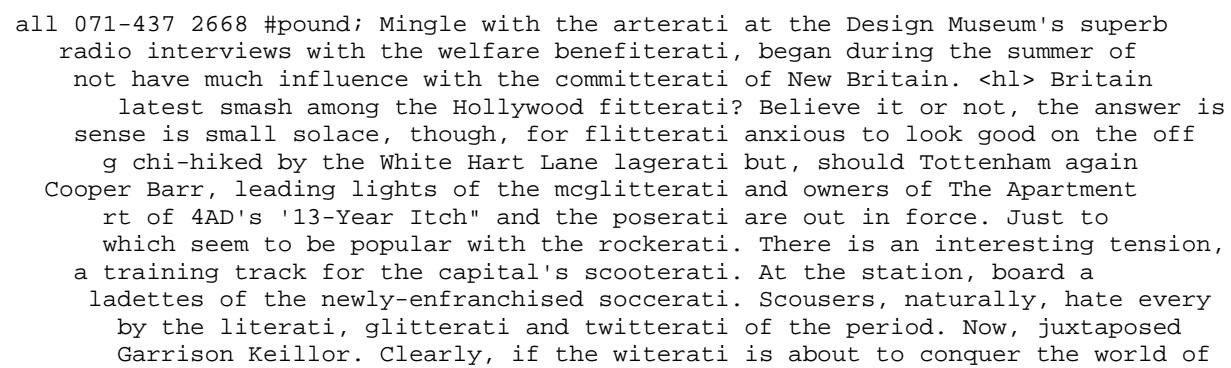

While literati can be used neutrally, almost all other formations are used ironically and deprecatingly. ${ }^{8}$

\subsection{Dictionary treatment}

The learners' dictionaries treat word formation in two ways: through individual entries for the most productive affixes and through special features, which explain principles and systems, and/or list, gloss, and exemplify affixes. Uberis explained as follows:

LDOCE4: informal better, larger, or greater; = super: uberbabe Pamela Lee | I want to do something uber-cool with my webpage.

OALD7: (informal) (in nouns and adjectives) of the greatest or best kind; to a very large degree: His girlfriend was a real uber-babe, with long blonde hair and a big smile. $\diamond$ The movie stars the uber-cool Jean Reno. 
MED2: often humorous 1 very: used with adjectives: My new sneakers are uber-cool. 2 total, or complete: used with nouns: This is the web page of an uber-nerd. jet-setting uber-babe Mischa Barton.

These entries are not inaccurate, but nor do they satisfactorily explain combinatorial patterns and the manneredness or negativity of less recurrent forms. Entries for -esque are as follows:

LDOCE4: 1 in the manner or style of a particular person, group, or place: Kafkaesque ( $=$ in the style of the writer Franz Kafka) 2 having a particular quality: picturesque (= pleasant to look at)

OALD7: in the style of: statuesque $\diamond$ Kafkaesque

MED2: 1 used with the names of some people to make adjectives describing things relating to that person or their work: Kafkaesque bureaucracy 2 used with some nouns to make adjectives describing things that have a particular quality: $a$ picturesque landscape

The most striking point here is that Kafkaesque is used to illustrate the formation, yet this is hardly compositional: it has a particular meaning 'nightmarish, bewildering', alluding to situations described in Kafka's work, rather than simply describing his work or style - and in fact both OALD7 and MED2 have separate entries which well describe exactly this sense.

Literati is a more complex case: it has become a model, but can scarcely be decomposed into a suffix -erati. All three dictionaries treat literati and glitterati; MED2 has chatterati, though with a different meaning from Indian English. Nothing more is said, and perhaps all that could be added is some kind of cross-referencing between the forms, or a comment that analogous hapax forms occur.

\section{Idioms}

\subsection{Variability and instability}

Idiom is an ambiguous term, but is most narrowly applied to a subclass of fixed expressions with non-compositional meanings: metaphorical phrases such as bury the hatchet, spill the beans, through thick and thin. Ad hoc exploitations are regularly found - for example, BoE has spill the enchiladas/flageolets/haricots and corpus research in general has provided extensive evidence of idiom instability and variation: see, for example, Moon 1998: 120ff.

To begin with the idiom exploited in the example 'Out of the frying pan into the deep freeze ...' (Carter 2004: 95), typical realizations in BoE are:

go out of the frying pan (and) into the fire jump from the frying pan into the fire 
it's out of the frying pan into the fire out of the frying pan ... [with ellipsis]

Exploitations include, with the first paralleling Carter's example:

Escaping the heat of Calcutta, it's out of the frying pan into the freezer.

In the last few months, however, these adventurers have discovered that they have leapt from the frying pan into the flames of the deepest recession to hit America since the 1930s.

I really liked Kenneth. But it was a case of out of the frying pan and into the volcano. Sometimes he would disappear and phone to say he was on his way home then take six hours to get there.

Greece [sc. football team] proceeded from the fire into the frying pan on Saturday ...

In the case of pigs might fly, typical variations are pigs may/will/can't fly, and BoE also provides many examples such as:

Do you believe the British press would behave honestly and calmly, without malice or bias? Look out of the window. Is that a pig flying by?

But until perfect pigs are spotted flying in the sky, they would be wise to stop promising things they cannot deliver.

They were looking for flying pigs when the West Indies set off in pursuit of a victory target of 364 . What they got was the sight of chickens coming home to roost as they collapsed pitifully to 51 all out, their lowest Test score.

The forms in which traditional proverbs are found can also vary greatly: many are less often found as independent clauses (a drowning man will clutch at a straw; it's the last (straw) that breaks the camel's back) than as verb + complementation idioms (clutch at straws) or noun compounds (the last straw). For example, BoE has examples of the proverb every cloud has a silver lining but many more of silver lining on its own (around $60 \%$ of all tokens); further examples allude in some way to clouds, which represent metaphorically a disadvantageous situation, and some even reverse the form of the proverb:

There's no point in being depressed about it because every cloud has a silver lining.

Indeed, yesterday was one of those occasions when policy-makers seemed intent on finding a silver lining.

The only silver lining in the clouds is the unofficial opposition, the unsung heroes and heroines, who despite the massive and near-absolute power of the state, have never given up the struggle ...

This is the sparkle of gold in the dust of unemployment, the silver lining in the cloud of apathy, the light at the end of the tunnel of hopelessness. 
On the surface then, Ronnie O'Brien's move to Italy was a silver lining at the end of this cloudy spell.

The bay area may be the one major city that's had a good '92, but it's a case of every silver lining having a larger black cloud. The Athletics won their division but then lost the playoffs because their hero, the unloseable reliever, Dennis Eckersley, lost when it counted.

Perhaps the most creative idiom phenomenon is the frame: cases where there are no fixed lexical words at all but an underlying structure which signals and creates the idiomatic meaning. One such can be glossed as 'unintelligent, foolish', and its best-known realizations include:
two sandwiches short of a picnic several cards short of a full deck
a brick short of a full load
a few beers short of a six-pack

BoE has, however, many further realizations, which are intended to amuse and typically relate cohesively to the context, or represent metonymically the person being described or their activities. Creativity is thus the norm:

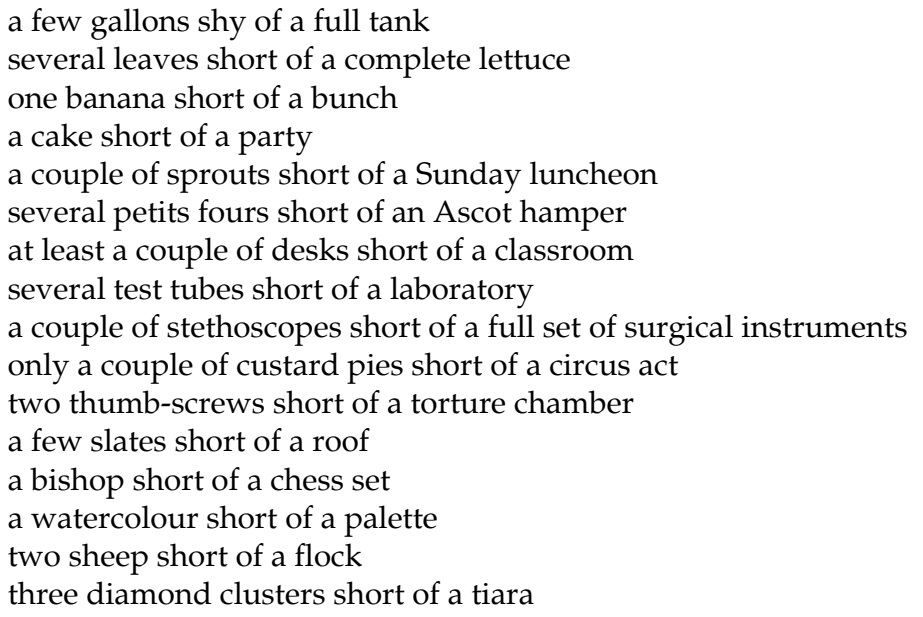

\subsection{Dictionary treatment}

General dictionaries tend not to allocate much space to metaphorical idioms such as these, so only the best established of variations are shown, examples are sparse, and information is aimed primarily at decoding. Explanations of out of the frying pan ... in the three learners' dictionaries are broadly similar; none give examples, nor show collocating verbs: 
LDOCE4: out of the frying pan and into the fire to go from a bad situation to one that is even worse

OALD7: out of the frying pan into the fire (saying) from a bad situation to one that is worse

MED2: out of the frying pan (and) into the fire used for saying that someone who was in a bad situation is now in a worse situation

All three dictionaries cover pigs might fly by explaining its pragmatics, and, in the case of OALD7, the American variant when pigs fly:

LDOCE4: spoken used to say that you do not think something will happen: 'Someone might have handed in your pass.' 'Yes, and pigs might fly.'

OALD7: (ironic, saying) used to show that you do not believe sth will ever happen. 'With a bit of luck, we might be finished by the end of the year.' 'Yes, and pigs might fly!'

MED2: British spoken used for saying that something is completely impossible

All three dictionaries treat every cloud has a silver lining at the headword cloud, ${ }^{9}$ but not the elided form silver lining. ${ }^{10}$

Two sandwiches short of a picnic (etc.) is covered in two of the learners' dictionaries, under short:

LDOCE4: be one ... short of a ... spoken used humorously to say that someone is a little crazy or stupid: Lady, are you a few aces short of a deck? | He's one sandwich short of a picnic.

OALD7: a brick short of a load, two sandwiches short of a picnic, etc. (informal) (of a person) stupid; not very intelligent.

LDOCE's citation form is perhaps harder to interpret than OALD's, but the definition covers pragmatics more successfully.

Variability is a significant aspect of idiom behaviour, and some attempt to acknowledge this is made in the special features on idioms in LDOCE4 and OALD7 (though not MED2). LDOCE4 has:

Idioms are normally used in a very fixed and limited way. Often, though, English speakers play with idioms by making up their own versions of an existing idiom.

It illustrates this with the pattern it drives me crazy/nuts/mad/up the wall/bananas. OALD7 has:

In some idioms, many alternatives are possible. In the expression disappear into thin air, you could replace disappear with vanish, melt or evaporate. In the dictionary this is shown as disappear, vanish, etc. into thin air, showing that you can use other words with a similar meaning to disappear in the idiom ... 
Both dictionaries here refer to the more tractable side of idiom variation, and it is perhaps a pity that space constraints did not permit them to add something about more extreme and creative forms.

Specialist dictionaries of idioms have more scope, and, for example, particular attention is paid to variation in the Oxford Dictionary of English Idioms (1993, henceforth ODEI), ${ }^{11}$ which has a special index of variations, and the Collins Cobuild Dictionary of Idioms (1995, henceforth CDI). To demonstrate something of the possibilities: ODEI's entry for pigs might fly has a slightly overliteral definition ('wonderful, and seemingly impossible, things may happen'), but its three examples include a gross variation and pragmatics-oriented note, while CDI adds a note on variability:

ODEI: ... (NONCE) If each individual were morally regenerated ..., the world could become a better place. Equally, if pigs had wings, they might be taught to fly. $\square$ variant 'if pigs had wings, they might be taught to fly'; implies speaker does not believe that things referred to will happen.

CDI: People often vary this expression, for example by saying they saw a pig flying by. 'Maybe one day we'll be seen as entertaining.' 'Oh look, I just saw a pig fly by my window.'

ODEI treats every cloud has a silver lining as a headphrase form, but examples show variation including the reversal, and a note on variability and pragmatics (CDI's long entry deals with truncation, reversal, and exploitations):

... Patrick decided things were far from bad just now. Even an alcoholic cloud may turn out to have a silver lining if taken in time. $\square$ (NONCE) He turns out to be considerably less pessimistic than most writers whom we think of as 'serious', for whom every silver lining was a cloud $\square$ often adapted; often said to encourage oneself or sb else.

The 'two sandwiches' frame is not included in ODEI, but CDI comments explicitly on its variability and creativity, and its examples, omitted here, cover two 'canonical' variations and two creative ones:

Short of is used in expressions such as 'one sandwich short of a picnic' or 'several cards short of a full deck' to indicate in a humorous way that you think someone is very stupid or behaving very strangely ... This expression is used very creatively, and people often use it simply for the humorous effect of a new and amusing variation.

\section{Respellings}

\subsection{Changing forms, changing usage}

My final examples of linguistic creativity relate to spelling. Ad hoc creativity regularly occurs, for example in newspaper headlines and in electronic personal correspondence, whether private or semi-public, but corpus data is not 
really the best source of data to investigate it. However, some respelled forms such as ker-azy do recur in BoE:

... find yourself hailed as Harbingers of ker-azy new scene.

His guests include the Doug Anthony All-Stars, ker-razee comedians.

... ker-razy beer boy singer Jerry A ...

More relevant for lexicography are cases where respellings become institutionalized, developing special meanings and usages of their own. Lite, originally an informal American respelling of light, began to be used as an indicator that food had less fat or calorific content, or drinks had less alcohol, than standard:

The meaning of 'natural" has been subverted by being coupled with 'diet" food. Diet food, also called 'lite" food, accounts for a major proportion of the food industry's growth.

The Marks \& Spencer Lite yogurt range is an unbeatable combination of fruit and wholesome yogurt.

It is now regularly used, postnominally, to deprecate something as an oversimplified or weakened form of an original, more challenging or demanding, activity, subject, and so on:

The result is that he serves us up with history lite, something much less appetising than the real thing.

Martin Amis ... objects that the biography and the interview are a sort of Literature Lite for those too lazy to take the real thing: 'The truth is that we are more interested in writers than we are in writing.'

Environmental groups criticised the 'watered down" deal. Greenpeace described it as 'Kyoto-Lite".

Pastels, a sort of 'colour lite" for those too scared of the real thing, run the real risk of looking twee and faint-hearted.

Similarly, in British English the respelling yoof ${ }^{12}$ is used to refer, often disparagingly, to youth culture and language, while girrl (with varying numbers of $r$ and $l$ ) denotes a spirited and confident young woman:

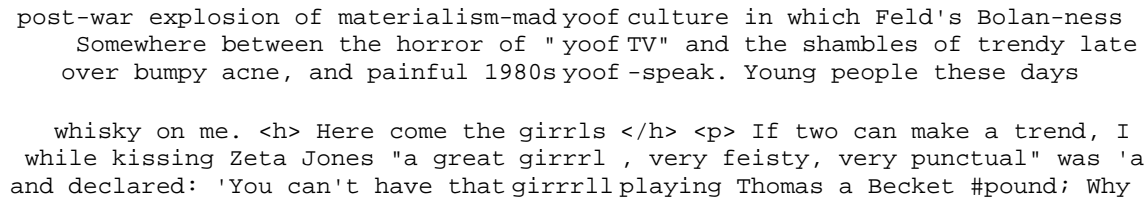

These are spelling innovations which, arguably, fill semantic gaps.

The case of it bares out research is perhaps different. While it would normally be considered an error (though this form could be interpreted as realizing the same metaphor as in lay bare, 'make evident, reveal'), it is representative of 
other cases where erroneous spellings co-exist with standard ones. Many of these involve homophonous or near-homophonous words, as in the following, where the canonical or original form is given first:

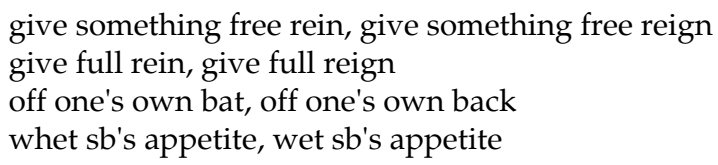

Evidence from corpora, web data, and elsewhere suggests that the 'non-standard' forms are now in free variation with their originals, and may well supplant them. As with bear/bare out, respelled/misspelled forms are rationalizable, for example, through different metaphors: off one's own bat is a cricketing metaphor, off one's own back could suggest a metaphor to do with getting up and becoming active; whet someone's appetite involves a metaphor to do with sharpening, ${ }^{13}$ wet someone's appetite suggests a metaphor to do with providing an appetizer or aperitif. ${ }^{14}$

\subsection{Dictionary treatment}

Only the best-established non-standard spellings feature in learners' dictionaries. All three have lite in the context of low-calorie/-fat foods and low-alcohol drinks, but only OALD7 has a second sense:

2 (used after a noun) (disapproving) used to say that a thing is similar to sth else but lacks many of its serious or important qualities: I would describe this movie as 'Hitchcock lite'.

All three deal with yoof, though none (unsurprisingly) with forms of girrl:

LDOCE4: adj [only before noun] BrE relating to or intended for young people used humorously: a yoof magazine

$n$ [U] BrE young people, considered as a group — used humorously: British white yoof

OALD7: (BrE, informal, humorous) a non-standard spelling of 'youth', used to refer to young people as a group, especially as the group that particular types of entertainment, magazines, etc. are designed for $\mathbf{y o o f}$ adj. [only before noun]

MED2: British very informal humorous young people. This word is used especially on television, in the newspapers etc, as a humorous way of spelling the word 'youth': today's yoof the new face on yoof TV

The three attribute yoof to different registers; the label humorous is perhaps intended to subsume the slight disparaging quality of the use of yoof.

None of the three dictionaries covers erroneous or changing spellings of the idioms mentioned. At a more general level, though, MED2 deals with creative respelling in its study page feature on word formation: 
... Sometimes they develop different meanings from the original versions: for example, the word wannabe is a respelling of the phrase want to be, but it is used as a noun meaning someone who wants to be famous or successful.

\section{Implications}

In the preceding sections, I have discussed a range of lexical phenomena which demonstrate something of the systematic creativity of language in use. The cases selected were simply some which I had noticed and investigated: not, of course, a scientific approach. Yet I would argue that they are nonetheless representative, since for each type, whether loose metaphorical use, pragmatic signal, frame, affix, idiom, or respelled item, many more examples could be found with similar productive patterns of creative usage: hence their systematicity. My choice of dictionaries has also been deliberately limited, and perhaps others succeed in areas where these, arguably, do not - though in fact the three are all very successful dictionaries, written with great skill and thought, and taking into account a variety of evidence sources; moreover, each one deals well with individual instances of a creative phenomenon. I must emphasize, too, that lexicographers are certainly not unaware of creative phenomena, since these uses are precisely the ones which they separate from 'central and typical' usage in the evidence. The question is, however, whether such uses need be entirely discarded in the way that they so often are.

A whole array of creative linguistic phenomena are readily findable in corpora, as search engines permit. These are not just oddities or ad hoc neologisms, but realizations of systematic creativity in language. Smaller dictionaries are necessarily limited in what they can do or show or explain, but by omitting such phenomena, or by treating them 'lightly', they neglect an important aspect of language. This has consequences for dictionary users with respect to decoding, because of the connotations and pragmatics: there are also consequences for encoding, since comfort and confidence with a language comprises more than just fluency and grammatical competence. After all, language learners and non-native speakers, as native speakers, are not oblivious to creativity, puns, and metaphoricity. Lexicographers may therefore be doing their users a disservice: in presuming that users do not want or need further comment or coverage, in neglecting the evidence of corpora, and, not least, in passing up an opportunity to communicate the sheer fun of a language as well as ways in which usage is practised or changes. ${ }^{15}$ If dictionaries do not discuss these creative phenomena, it is difficult to see how or where users can find reliable information about them, and thus find out about the meanings of the language and discourses with which they are engaging. This, it seems to me, is frustrating for everyone, not least lexicographers themselves.

\section{Notes}

1. In contrast to 'subversive' dictionaries, such as those of slang or neologisms, though these are generally more interested in actual formations than patterns of formation. 
2. For example, where words change word class (noun $=$ form of transport $\rightarrow$ verb $=$ be conveyed by that transport: bike, ship, motor, etc.) or nouns change countability (uncountable noun $=$ substance $\rightarrow$ countable noun $=$ types or portions of that substance: cheese, wine, bread, etc.

3. With respect to neologism and lexicography, see, for example, discussion by Svensén (1993: 40ff), Landau (2001: 202ff), on headword selection; Hanks (2005: 248-9) on Samuel Johnson, lexical creativity, and institutionalization; and Prinsloo and Gouws (2006) on neologism and longevity.

4. The Bank of English corpus was created by COBUILD at the University of Birmingham. It comprises 450 million words (approximately 71\% British English, 21\% North American English, 8\% Australian English), mainly taken from 1990s written sources but including over 20 million words of spoken interaction and 40 million words of transcribed radio broadcasts.

5. Veritable is discussed by Sinclair (2003: 91-103), who draws attention to its metaphorical collocates. Krishnamurthy (1987: 81-85) uses veritable to demonstrate compilation procedures on the COBUILD project.

6. The prefix sub-can also have this meaning: sub-Orwellian, sub-Wagnerian etc.

7. Mcglitterati are Scottish glitterati; lagerati are supporters of a football team; twitterati parallels chatterati, but with implications of the worthlessness of their comments.

8. See Kemmer (2003: 73-4, 82ff) for discussion of words in -erati from morphological and cognitive perspectives.

9. OALD7 repeats it in its appendix of sayings and proverbs, as it does out of the frying pan into the fire.

10. Silver lining is a compound headword in Collins Cobuild English Dictionary (1995: 2nd edition), which was based on BoE; also in its first edition of 1987.

11. ODEI is a republication, with minor revisions, of Oxford Dictionary of Current Idiomatic English. Volume 2: Phrase, Clause and Sentence Idioms (1983).

12. Influenced by a non-standard but fashionable pronunciation of $/ \mathrm{f} /$ for $/ \theta /$.

13. The same metaphor is found in keen: literally 'sharp', metaphorically enthusiastic.

14. Recurrent misspellings such as these, based on mishearings or misinterpretations, are sometimes referred to as 'eggcorns' (Mark Liberman's term (from a mishearing of acorn as eggcorn): for example, bare-faced lie, bear-faced lie; foolproof, full proof; lip-sync(h), lip-sing; throes of passion, throws of passion. See the website http://eggcorns.lascribe.net.

15. This can be related to current discussions about whether corpus- and frequency-determined selection of lemmas etc. for dictionaries corresponds appropriately to the kind of information sought by users, as demonstrated through log file records of look-ups: see De Schryver et al 2006, Bergenholtz and Johnsen 2007.

\section{References}

\section{Dictionaries}

Cowie, A.P., R. Mackin and I. McCaig. 1993. Oxford Dictionary of English Idioms. Oxford: Oxford University Press. (ODEI)

Pearsall, J. (Ed.). 1998. New Oxford Dictionary of English. Oxford: Oxford University Press. 
Rundell, M. (Ed.). 2005. Macmillan Phrasal Verbs Plus. Oxford: Macmillan.

Rundell, M. (Ed.). 2007. Macmillan English Dictionary for Advanced Learners. Second edition. Oxford: Macmillan. (MED2)

Sinclair, J. and S. Bullon (Eds.). 1995. Collins Cobuild English Dictionary. Second edition. London/Glasgow: HarperCollins.

Sinclair, J. and R. Moon (Eds.). 1989. Collins Cobuild Dictionary of Phrasal Verbs. London/Glasgow: HarperCollins.

Sinclair, J. and R. Moon (Eds.). 1995. Collins Cobuild Dictionary of Idioms. London/Glasgow: HarperCollins. (CDI)

Summers, D., S. Bullon and A. Gadsby (Eds.). 2003. Longman Dictionary of Contemporary English. Fourth edition. Harlow: Longman. (LDOCE4)

Wehmeier, S. (Ed.). 2005. Oxford Advanced Learner's Dictionary of Current English. Seventh edition. Oxford: Oxford University Press. (OALD7)

\section{Other literature}

Aitchison, J. 2007. The Word Weavers: Newshounds and Wordsmiths. Cambridge: Cambridge University Press.

Apresjan, J. 1974. Regular Polysemy. Linguistics 142: 5-32.

Bauer, L. 1983. English Word-Formation. Cambridge: Cambridge University Press.

Bergenholtz, H. and M. Johnsen. 2007. Log Files Can and Should Be Prepared for a Functionalistic Approach. Lexikos 17: 1-20.

Carter, R. 1999. Common Language: Corpus, Creativity and Cognition. Language and Literature 8(3): 195-216.

Carter, R. 2004. Language and Creativity: The Art of Common Talk. London: Routledge.

Chiaro, D. 1992. The Language of Jokes: Analysing Verbal Play. London: Routledge.

De Schryver, G.-M., D. Joffe, P. Joffe and S. Hillewaert. 2006. Do Dictionary Users Really Look Up Frequent Words? - On the Overestimation of the Value of Corpus-based Lexicography. Lexikos 16: 67-83.

Hanks, P. 1987. Definitions and Explanations. Sinclair, J.M. (Ed.). 1987. Looking Up. An Account of the COBUILD Project in Lexical Computing and the Development of the Collins COBUILD English Language Dictionary: 116-136. London: Collins.

Hanks, P. 2005. Johnson and Modern Lexicography. International Journal of Lexicography 18(2): 243266.

Katamba, F. 1994. English Words. London: Routledge.

Kemmer, S. 2003. Schemas and Lexical Blends. Cuyckens, H., T. Berg, R. Dirven and K.-U. Panther (Eds.). 2003. Motivation in Language: Studies in Honor of Günter Radden: 69-97. Amsterdam: John Benjamins.

Kövecses, Z. and P. Szabó. 1996. Idioms: A View from Cognitive Semantics. Applied Linguistics 17(3): 326-55.

Krishnamurthy, M. 1987. The Process of Compilation. Sinclair, J.M. (Ed.). 1987. Looking Up. An Account of the COBUILD Project in Lexical Computing and the Development of the Collins COBUILD English Language Dictionary: 62-85. London: Collins.

Lakoff, G. and M. Johnson. 1980. Metaphors We Live By. Chicago: University of Chicago Press. 
Landau, S.I. 2001. Dictionaries: The Art and Craft of Lexicography. Second Edition. Cambridge: Cambridge University Press.

Lindstromberg, S. 1997. English Prepositions Explained. Amsterdam: John Benjamins.

Maybin, J. and J. Swann. 2006. The Art of English: Everyday Creativity. Basingstoke: Palgrave Macmillan/Open University.

McCarthy, M. 1998. Spoken Language and Applied Linguistics. Cambridge: Cambridge University Press.

Moon, R. 1998. Fixed Expressions and Idioms in English: A Corpus-based Approach. Oxford: Oxford University Press.

Nash, W. 1985. The Language of Humour. Harlow: Longman.

Nunberg, G. and A. Zaenen. 1992. Systematic Polysemy in Lexicology and Lexicography. Tommola, H., K. Varantola, T. Salmi-Tolonen and J. Schopp (Eds.). 1992. EURALEX '92 Proceedings. Papers Submitted to the 5th EURALEX International Congress, Tampere 1992: 387-396. Tampere: University of Tampere.

Ostler, N. and S. Atkins. 1991. Predictable Meaning Shift: Some Linguistic Properties of Lexical Implication Rules. Pustejovsky, J. and S. Bergler (Eds.). 1991. Lexical Semantics and Knowledge Representation: 76-87. Berkeley: University of California.

Prinsloo, D.J. and R. Gouws. 2006. Fashion Words in Afrikaans Dictionaries: A Long Walk to Lexicographic Freedom or Just a Lexical Fly-by-Night? Corino, E., C. Marello and C. Onesti (Eds.). 2006. Proceedings XII EURALEX International Congress, Turin, Italy, September 6th-9th, 2006: 301-312. Alessandria: Edizioni dell'Orso.

Sinclair, J. 2003. Reading Concordances: An Introduction. Harlow: Pearson Longman.

Svensén, B. 1993. Practical Lexicography. Oxford: Oxford University Press. 